\title{
Digital Marketing Communication Development On Micro, Small And Medium Enterprises (Msme) In Era 4.0 Based On Sharia Economic (Case Study Msme Domas Village, Pontang District)
}

\author{
Syihabudin ${ }^{1}$, Rangga Galura Gumelar ${ }^{2}$ \\ \{syihabudin@untirta.ac.id ${ }^{1}$, rangga.gumelar@untirta.ac.id² \\ ${ }^{1}$ Lecturer Study Program Ekonomic Sharia Islam, University of Sultan Ageng Tirtayasa, Jl. Raya Jakarta \\ KM.4 Pakupatan, Serang-Banten, Indonesia \\ ${ }^{2}$ Communication Science, University of Sultan Ageng Tirtayasa, Jl. Raya Jakarta KM.4 Pakupatan, \\ Serang-Banten, Indonesia
}

\begin{abstract}
The development of Micro, Small and Medium Enterprises (MSME) based on Islamic sharia economic law, should be developed not only on capital requirements which then serve as an important role in the management of MSME, but the current challenges in the 4.0 era, network expansion and media use are absolutely necessary. Marketing system in this era is not focused on the area of limited nature, but has entered the digital marketing area, where the actual market share is wider and more numerous. Therefore, with based on the sharia economic approach it needs a synchronization and development in MSME to be able to innovate and develop in the direction of digital marketing. The focus of research on MSME in the District of Pontang, Domas Village, Serang Regency, Banten Province, is based on the typical food "Bontot" which uses payus fish as its main ingredient, until now it still uses conventional marketing methods and approaches. With a qualitative approach and interview method, observation to documentation found that Bontot_Omkumz MSMEs has been able to optimize the use of the social media application, Instagram as an important part in marketing its products. The influence of digital marketing, which is accompanied with honesty and personal approach, is the key for people to believe in the bontot products. Some things that need to be considered 1) Keep maintaining the uniqueness of the product; 2) Increase an interesting and interactive innovations on social media's content; 3) Apply and prioritize the values in accordance in Islamic law.
\end{abstract}

Keywords: Sharia Economy, Digital Marketing, Bontot Pontang

\section{Introduction}

Changes and developments in the information of technology are directly proportional to the changes and patterns of human habits in general. The appearance of new media that uses internet facilities provides an opportunity and space for everyone to use communication channels that are so diverse and can almost be said without limits. Indeed this is an opportunity especially for MSME to be able to expand their market share. Buyers now are no longer the typical who must meet with sellers to get the items needed, but they are more likely to believe in shows or advertisements on social media or on the internet. This condition is actually a challenge and a possibility for MSME to be immediately arrested and developed in the marketing process.

Phenomenon in Indonesia today, almost everyone and even small children have gadgets or smartphones in their daily lives, and it can almost be said that these objects are primary 
needs at this time. Smartphone users in Indonesia are up to 103 million in 2018 [1] even internet users in Indonesia reached 171.17 million in 2018, up from the previous year in 2017 of 143.26 million people [2], there are still many internet users in the island of Java as much as $55.7 \%$, where Banten Province accounts for $4.8 \%$ of internet users. With these conditions, there will be a trend of change and an increase in the pattern of product marketing, [3] no longer relies on conventional marketing but is more inclined to a creative marketing by using the digital marketing. Digital marketing activities that based on the online marketing, will be felt more easily, especially for people who are accustomed to using the online systems.

Nearly $48 \%$ of internet users in Indonesia, use online applications to buy and get goods or services online and usually the applications that used in these searches are the social media such as Facebook, Instagram, Twitter, Youtube and even now applications like Whatsapp can used as a channel to promote their merchandise. It must be admitted, that the utilization and use of this new media channel is not an easy and fast matter to be adopted by the public, especially the micro, small and medium enterprise's worker in Indonesia. The data reported by McKinsey stated that only $30 \%$ of marketing utilization through digital marketing in Indonesia. It must be admitted that the use and utilization of digital marketing is not easy, not just displaying and uploading product photos, but must be accompanied by perseverance, creativity and sustainability, including resources that have expertise in IT.

It must be admitted that MSME is one of the foundations of people's economy that has an important role at improving the economy of families to small and medium communities. One of the interesting MSME to be examined is the MSME that are engaged in selling Banten special foods from Domas Village, Pontang District, Serang Regency, namely Bontot which is made from the basic ingredients of payus fish. The uniqueness of this phenomenon is how the marketing changes made by MSME in Domas Village are not limited to conventional face-to-face marketing, but have transformed and developed their marketing patterns using digital martketing principles, but in marketing they still use the Islamic principles. The Pontang area, especially the Domas Village, is well known for its people who hold high patrons and religious values, with the term Ta'wun [4].

\section{Literature Review}

\subsection{Sharia Economic Base in MSME Marketing}

There are no differences between Islamic Economics and Sharia Economics, because both emphasize the concept and application in accordance with Islamic law. The understanding of sharia is interpreted very broadly not only in the field of trade, but also in the fields of law, justice and family [5]. The current particular developments in Indonesia, especially exist in Islamic economic values turned out to be a true and appropriate concept because it refers to the norms of Islam, justice, transparency, also prioritize the interests and welfare of society. Because basically economic activity is a good activity in accordance with the a'maal shaalihaat [6] because in it there is a dimension of worship both to fellow humans and Allah.

In some of the western paradigm marketing [7] are focuses on marketing in the context of the design and activities only and [8] which sees marketing in terms of mere needs, whereas in general it is explained that marketing through the concept of sharia is based on the understanding of the Al-Quran and Al-Hadith, wherein there is fairness and transparency both from the seller and the buyer so that they are loose from the vanity [9]. Three elements [10] in sharia marketing that must exist, are 1) Theitis (Rabbaniyah), are beliefs in sellers themselves 
based on the Blessed Allah SWT; 2) Ethics are attitudes and behaviors that are developed by sellers in accordance with the provisions of Religion; and 3) Realistic is honesty, not lying or exaggerating to consumers. It is clearly seen that in the context of western thought, profit orientation is absolutely essential while the principle in Islamic economics is honesty and transparency in accordance with Islamic norms and rules [11].

\subsection{Relationship of Digital Marketing and MSME}

The concept of digital marketing is no longer the traditional system but marketing through digital media [12] as well as social media or e-commerce. In this context mastery of digital technology as a potential channel to reach the number of consumers according to their needs. An effective way to implement the digital marketing concept by MSME is to use and utilize social media, even this channel seems to provide space to build a more personal relationship between MSME businesses and their consumers. Marketing using online media actually does not require huge costs, because online media or social media provide a huge space for us to do a variety of activities and creativity.

\section{Research Methodology}

This research is using a descriptive qualitative approach, where the researchers try to describe the conditions in the field through observation and interview methods [13], so that they can interpret what is seen holistically [14]. The research subject was MSMEs Bontot Traders in Domas Village. Based on the data source, it is divided into primary and secondary data where primary data is generated through in-depth interviews and observations both in text and in the field, while for secondary data obtained from books or literature that supports the strengthening and research needs [15].

\section{Results and Discussion}

This research focuses on Pak Umz's bontot business or known as "Om Kuz" bontot. This bontot business is classified as micro business based [16], because it was founded by individuals and classified as having a capital under 50,000,000. There are three food products produced by this MSME, there are Bontot, Lengkur (Sate Bandeng) and Fish Crackers. The price offered in Bontot Payus Fish 400g is Rp. 15,000, Payus Fish Crackers 250g is Rp. 15,000 and Lengkur or Sate Bandeng Rp. 25,000. The management of this business is carried out by one family, so it is practical that those who work in making this product are done by relatives.

The personal approach to selling is very visible, where the business owner is always asking about how the taste of his product, as well as actively posting a thank you to customers for purchasing his products. This Bontot sales, is not just in addition to promoting the personal approach, but these sales put forward the elements of honesty, transparency and no fraud. The example is that in the production of Bontot products, the raw material used is the original raw material of payus fish, not mixed and replaced with other fish. This can be happen, sometimes the production of payus fish is not always much, so there are vendors who replace it with other fish. Another principle of honesty in marketing this product is price, it is always expressed that the price of capital to consumers and the benefits they get. With this principle of honesty, business owners are even increasingly trusted and get profit even sometimes the tips they get exceed the profit margins they set in the Bontot products. 
This Bontot Om Kumz producer realizes that it requires a large amount of capital if he has to rent a shop for his business, apart from that marketing which is done by door to door for the moment is probably not appropriate. For this reason, these products are sold using online media applications, recorded online media used in marketing are Facebook, Instagram, Whatsapp and even Youtube. This application was chosen because it is classified as easy to use and has a broad reach also can be applies to all segments and groups in the community. This is because that almost the average people whether it's parents, teenagers and even children are now hold and spend time with gadgets. Promotions done on social media, especially on Facebook and Instagram use the principle of honesty. Postings of images that are displayed in accordance with what is there, only play at the angle. Another promotion that is displayed is, how is the free delivery promotion for the Serang area, this becomes interesting because the customer is facilitated and feels that the goods he bought feels cheap because there is no additional delivery fee and so on, although for this delivery there is a minimum order of 2 pcs, however this is still considered reasonable. However, this promotion on Facebook, if you see it turns out that not many people respond and provide responses to the promotions offered.

This is very inversely proportional to Instagram which was just made in November 2017. There are almost 1,265 posts on IG bontot_omkumz. In the IG, in addition to promotions carried out in the form of posting Bontot product images, there are also many review posts or assessment results from the buyers of the Bontot products. Lots of captions or reviews both in the form of pictures and videos from buyers posted on the IG, and all of them gave positive comments on the bontot products. The number of followers in the IG was also fairly large, it's 3,842 followers and following 2,083. With this relatively large amount, it is clear that the marketing focus of these bontot products is on social media, IG. Indeed, if seen, at this time people tend to use IG, where currently the existence of IG is indeed the second largest after Facebook in Indonesia. The percentage can be seen at figure 1.

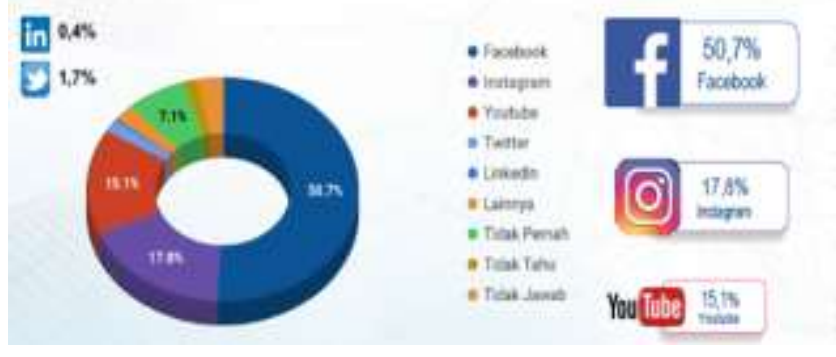

Fig. 1 : The percentage of social media uses in Indonesia. [17]

Based on the interviews, it was submitted that by selling online, at least it increased sales turnover and increased customer relations. From the virality of the writing as well as the stimulus that consumers provide, it gives a positive assessment and trust from the community, even Adhy Guntur Kumz as the account owner and also the bontot seller became one of the informants in the BPS survey, and became one of the MSME assisted by Disperindagkop Serang Regency. Even this bontot marketing, not only in Serang or in the province of Banten, but has also been sent outside the province of Banten, such as Palembang and even abroad, namely to Saudi Arabia. The innovations made in addition to marketing expansion, are also done on compressed bontot packaging, so that it is durable and not damaged for a long time. 


\section{Conclusions and Suggestions}

Based on the research above, MSME that are ready with changes and developments in information technology will be able to benefit and ease in marketing their products. It is clear that creativity and innovation become the main foundation in playing marketing using digital marketing. The influence of this digital marketing of course, undeniable and provides great opportunities especially for other MSME. Apart from that honesty and a personal approach that is the foundation as a key people believe in these Bontot products.

Apart from that, there are things that must be considered for improvement. 1) Maintaining the uniqueness of the product; 2) Continue to improve innovation, especially in making content on social media, which is interesting and interactive because it is very vulnerable to be copied later by the other competitors. One of them is by forming a creative team; 3) Apply and prioritize the values that are in accordance with Islamic law.

Acknowledgment. Big thanks to the International Conference on Islamic Development Studies (ICIDS) committee for accepting the author manuscript.

\section{References}

[1] C. Iswanaji, "Analysis of Accounting Information System Using Hot Fit Model Method in Indonesia Islamic Micro Financial Institutions," Appl. Financ. Account., vol. 5, no. 2, p. 1, 2019.

[2] Asosiasi Penyelenggara Internet Indonesia. (2019). Penetrasi \& profil perilaku pengguna internet indonesia. (March).

[3] McKinsey \& Company. (2015) Marketing \& Sales Big Data, Analytics, and the Future of Marketing and Sales. (March).

[4] P. K. Kannan and H. "Alice" Li, "Digital marketing: A framework, review and research agenda," Int. J. Res. Mark., vol. 34, no. 1, pp. 22-45, 2017.

[5] C. Muali and K. Nisa', "Pemasaran Syariah Berbantuan Media Sosial: Kontestasi Strategis Peningkatan Daya Jual," An-Nisbah J. Ekon. Syariah, vol. 5, no. 2, pp. 168 185, 2019.

[6] Syihabudin \& Ma'zumi. (2013). Nilai-nilai Ekonomi Dalam Perspektif Al-Quran. Hartomo Media Pustaka, Jakarta.

[7] Stanton, W.J.(2013). Fundamentals of Marketing. Mc Grow-Hill Book Company, USA

[8] Peter F. Drucker.: Harper \& Row Publiser Inc. Innovation and Entrepreunership Practice and Principles, New York (2008).

[9] Al-Qur'an dan terjemahannya. 2008. Departemen Agama RI. QS.(4)/29 Bandung: Diponegoro.

[10] Muali, C., Nisa, K., Nurul, U., \& Probolinggo, J. (2019). Pemasaran Syariah Berbantuan Media Sosial : kontestasi strategis. 05(April), 168-185.

[11] Arie Rachmat Sunjoto. (2011). Strategi Pemasaran Swalayan Pamella dalam Perspektif Islam. Vol. 1, No. 2, pp. 52-53. Jurnal Ekonomi Syariah Indonesia

[12] Kannan, P. K., \& Alice, H. (2017). Digital marketing: A framework, review and research agenda. International Journal of Research in Marketing, 34(1), 22-45.

[13] Jamshed, S. (2014). Qualitative research method - interviewing and observation. 5(4), 4-5.

[14] Personal, M., \& Archive, R. (2018). Munich Personal RePEc Archive Qualitative Research Methodology in Social Sciences and Related Subjects Qualitative Research 
Methodology in Social Sciences and Related Subjects. (85654).

[15] Kinn, S., \& Curzio, J. (2005). Integrating qualitative and quantitative research methods

[16] Enterprises, M. (2008). Small \& Medium Enterprise Development Policies in 6 ASEAN Countries MARCH 2008 Organization for Small \& Medium Enterprises and Regional Innovation, JAPAN. (March).

[17] Statista Research Department. (2019). Penetration of leading social networks in Indonesia as of 3rd quarter, Indonesian. (August) 